\title{
The role of public opinion in the sociological support of law- making activities
}

\section{Utkir MUKHAMEDOV ${ }^{1}$ Akhror KHUDOYBERDIYEV ${ }^{2}$}

Academy of the Ministry of Internal Affairs of the Republic of Uzbekistan

\section{ARTICLE INFO}

Article history:

Received September 2020

Received in revised form

15 September 2020

Accepted 15 October 2020

Available online

30 October 2020

\begin{tabular}{l}
\hline Keywords: \\
legal creativity \\
state authority \\
legislative branch \\
law-making \\
public opinion \\
sociology \\
sociological support \\
social researches.
\end{tabular}

\begin{abstract}
The article deals with theissues related to the sociological support of law-making activities, their essence and sociological research carried out in this process, taking into account public opinion in the process of law-making and legal aspects of sociological support of law-making process. At the same time the article analyzes a detailed analysis of the sociological support of lawmaking process, the role of public opinion in the lawmaking process, taking into consideration the results of the study of public opinion in the legislative process and the influence of sociological research on this process as well.
\end{abstract}

2181-1415/C 2020 in Science LLC.

This is an open access article under the Attribution 4.0 International (CC BY 4.0) license (https://creativecommons.org/licenses/by/4.0/deed.ru)

\section{Хуқуқ ижодкорлиги фаолиятини социологик таъминлашда ижтимоий фикрнинг ўрни}

\footnotetext{
Калит сўзлар:

хукуқижодкорлиги

давлат хокимияти

қонун чиқарувчи орган

қонун ижодкорлиги,

жамоатчилик фикри,

социология

социологик таъминлаш

социологик тадқиқотлар
}

\section{АННОТАЦИЯ}

Илмий мақолада хуқуқ ижодкорлиги фаолиятини социологик таъминлаш билан боғлиқ масалалар, уларнинг мохиятива ушбу жараёнда амалга ошириладиган социологик тадқиқотлар, хуқуқ ижодкорлиги жараёнида ижтимоий фикрни хисобга олиш хамда қонун ижодкорлиги жараёнини социологик таъминлашнинг хуқуқий жихатлари кўриб чиқилади.Шунингдек, илмий мақолада хуқуқ ижодкорлигини социологик таъминлаш, қонун ижодкорлиги жараёнида ижтимоий фикрни ўрни, қонун

\footnotetext{
${ }^{1}$ DSc, Professor, Academy of the Ministry of Internal Affairs of the Republic of Uzbekistan, Tashkent, Uzbekistan Email: utkirbek1977@mail.ru

${ }^{2}$ Candidate of law sciences, associate professor, Academy of the Ministry of Internal Affairs of the Republic of Uzbekistan, Tashkent, Uzbekistan Email: axrorxudoyberdiyev@mail.ru
} 
ижодкорлиги субъектлари томонидан қонун қабул қилиш жараёнида ижтимоий фикрни ўрганиш натижаларини инобатга олиш хамда социологик тадқиқотларни ушбу жараёнга таъсири масалалари атрофлича тахлил қилинган.

\section{Роль общественного мнения в социологическом обеспечении правотворческой деятельности}

Ключевые слова:
правотворчество
государственное власть
законодательная орган
законотворчество
общественное мнение
социология
социологическое
обеспечение
социологические
исследования

\section{АННОТАЦИЯ}

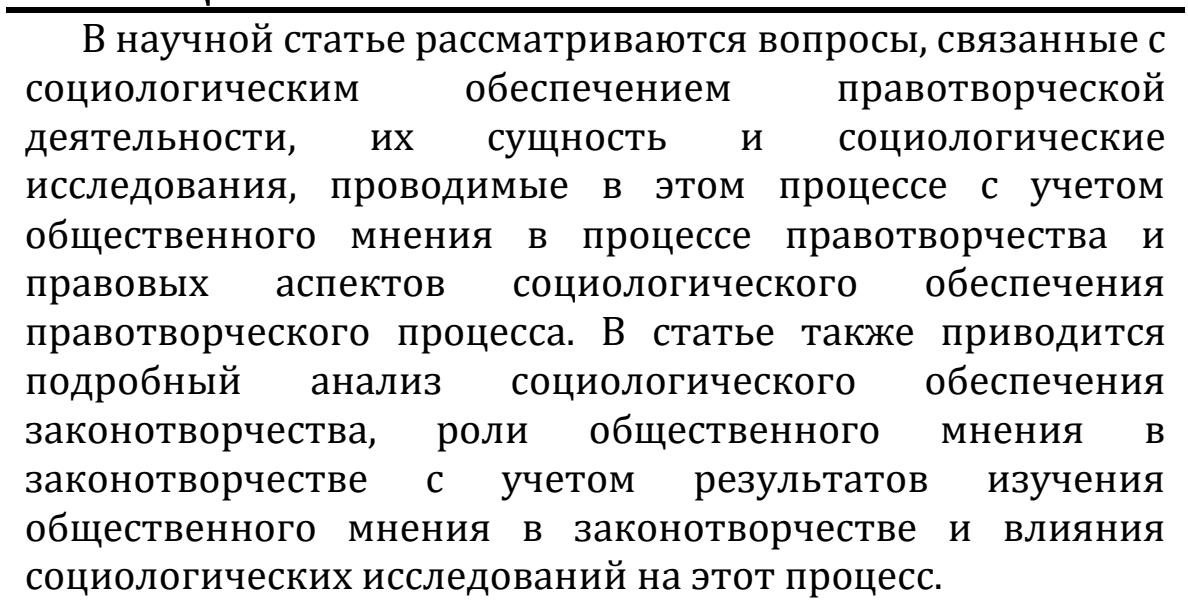

\section{INTRODUCTION}

A group of scholars including S.S. Alekseev, Yu.V.Arutyunyan, V.K.Babaev, M.A.Bokiy, B.L.Tolbaev, L.R.Broun, L.M.Drobijeva, J.Karbone, N.N.Kartseva, D.A.Kerimov, D.A.Kovachev, V.S.Korobeynikov, V.V.Lapaeva, M.N.Marchenko, M.A.Makeeva, F.E.Muhametshin, V.S.Nersesyants, S.V.Polenina, R.A.Safarov, Yu.A.Tihomirov, I.A.Fedyakin conducted research on the issues connected with law making process and public opinion in foreign countries.Particularly, M. Kerjner and A. Samandarov studied some issues connected with legal education taking into consideration of public opinion in prevention of offenses.

The issue of the role and importance of sociological research in the process of lawmaking process attracted the attention of sociologists of our country and abroad, including G.Spenser, E. Dyurkheim, M.Veber, V.V.Kasyanov, V.N.Nechipurenko, V.N.Dubovitskiy, G.V.Osipov, H.B.Saithodjaev, V.V.Varchuk, E.V.Maslovskaya, M.V.Maslovskiy.

The researchesof abovementioned authors are of great scientific importance. However, they did not widely study the theoretical problems of expression of public opinion in the legislative process of the Republic of Uzbekistan.

One of the most topical issue in the country is the direct participation of people in the legislative practice of the Republic of Uzbekistan and the sociological support of this process and determination of influence of public opinion to the law-making process.

\section{MATERIALS AND METHODS}

The sociological support of legal creativity cannot be imagined without practical research. In the sociological approach, law emerges not as an independent and separate phenomenon, but as a relatively independent phenomenon from the state, which is determined 
by social life, embodies the laws of social life. Law is an integral and subordinate part of the social system and performs a number of functions[2, p. 21].

The role of sociological research in the process of sociological support of legal creativity is invaluable. In general, sociological researches are a set of scientific, organizational, methodological and technical actions and procedures, combined for a single purpose, systematically received in order to obtain accurate information about the events and processes. Sociological research is conducted in order to collect accurate data and make conclusions on this basis about the characteristics of social and political events and processes and the principles of development[12, p. 277].

Thus, sociological research is a set of scientific, organizational, methodological and technical actions and procedures that are carried out in a systematic way combined for a single purpose to obtain accurate information about studied events and processes.

At present, specific knowledge of the object, subject, purpose, tasks, stages, types, measurement of social events and processes, data collection, analysis and generalization of sociological research has been collected[12, c. 277-299].According to this, the object of research is "the direction of research that the researcher wants to study and explain" [12, p. 280] or "social reality in a particular society" [9, p. 250]. The subject of research is the aspects, properties, laws of the object directly studied in this research. Typically, this is a manifestation of the current, most important aspects of the object at the moment.

Types of sociological research are distinguished based on the aim and tasks. The following types of sociological research distinguish in the literature: they are inquiry research, descriptive and analytical research.

Inquiry researches are preliminary studies that are organized to organize and conduct very in-depth and large-scale surveys. Such studies are conducted in the absence of any information about the object and subject of research.

Descriptive research, on the other hand, is conducted to gather information that helps to form a complete or partial picture of the event or process being studied. Such research is usually conducted to study the opinions of many people of different character.

Analytical research is the most serious research, which studies not only the structure of the studied phenomena, but their nature, significance, popularity, and so on as well. To do this, with the help of inquiries or descriptive research, information is collected that helps to form a certain idea about the aspects and symptoms of the phenomenon being studied[12, p. 283-284].

\section{RESULTS AND ITSDISCUSSION}

Sociologist H.B. Saitkhodjaev noted, "The science of sociology is closely linked with the empirical sociological research conducted in practice, and precisely these researchs determine the place of this science in society. Conducting empirical sociological research is a uniquely complex process that requires a certain amount of time and knowledge and skills, practical experience from the researcher.The process of conducting empirical sociological research covers several components and directions that are performed sequentially. First of all, a welldeveloped sociological research program, methods used in sociological research, analysis, generalization of empirical data obtained by them, the development of the necessary practical proposals, recommendations, researches, classification, collection of social facts is important $[9$, p. 247].

Today, the cooperation of public with public authorities, participation in important spheres of public life is of great importance, and the role of public opinion in all spheres of social 
life is growing. This can be clearly seen in the life of developed Western countries. In particular, he made conclusion about the important role of public opinion in the life of state and society that «positive action in the way of common interests of society»[1, p.12].

Also in the East, from ancienttimes, great attention has been paid to the diversity of opinions. Proof of this can be seen in the example of Uzbek folk proverbs, which are widely used in our lives. These include "A lot of ideas come out","A consultative wedding doesn't break up", "Second thoughts are best". At the heart of these proverbs is the need to think and act, including public opinion. In particular, Nizamulmulk commented on the role of public opinion in the implementation of laws: "If necessary, nothing is written in the parliament. The decree must be respected and enforced so that no one can leave it until it is implemented" [4, p. 77].

In our opinion, the role of laws in social life (although it belongs to the ancient world of politics) should be taken into account in the making of these laws ("Decree" in the quote) in order to ensure their long-term "implementation". "Apparently, in those times the attitude towards the king's order was studied and its execution was controlled.We believe that public opinion is a reflection of citizens' initiative, social activism, including their attitude to problems in the field of legislation. The importance of this can be seen in the following views of the President of the Republic of Uzbekistan."We need to read that without strong mass, public associations that maintain the balance in the structures of our society, there is no serious guarantee that there will be no vices in all branches of government, such as arbitrariness, voluntarism, authoritarian thinking and corruption"[3, p. 121].

These ideas proved once again the necessity to know public opinion through public, public associations, to use it in solving important issues of state importance.

"Arising of legal question isnatural: can public opinion have a significant influence on the development of society? "Social thought itself is in constant motion, strengthening its regulatory function and can develop under the influence of various changes and needs as society develops"[4, p. 58].

At the same time, in our view, taking into account the public opinion in the legislative process can be one of the factors that serve to improve the legislative mechanism and improve the bill, bringing them into effect with generally accepted international norms.As a result of disregard for public opinion in the legislative process, "the law may serve the interests of forces holding power, not for the interests of people"[8, p. 27].

Lawmakers, like sociologists, sometimes speak about public opinion (social ethics). As long as such a concept exists, there will be different opinions about it - there is reason to assume that it will be given to a certain extent the effect of applicable law. These include statutory sanctions.Yet lawmakers themselves understand that social thought is also shaped by other factors. Often, public opinion is taken into account when a new law is introduced, [6, p. 23]says Swedish Supreme Court Judge Stefan Magnusson.

Consideration of public opinion is inextricably connected with the principle of democracy, which is one of the basic principles of legislation. Consideration of public opinion in the legislative process essentially reflects the following:

- direct independence of subjects of legal creativity;

- direct participation of citizens in the development and adoption of regulations;

- relying on public opinion in adoption of regulations;

- transparency.

\section{CONCLUSIONS}


AT the same time, above mentioned elements create conditions and legal guarantees to ensure the interests of all segments of population that are reflected and implemented in the legislation, help to increase the effectiveness of legal acts in the implementation of national and local tasks.

At the same time, the consideration of public opinion in the legislative process is an important part of the mechanism of people's power and serves to ensure consistent democracy in this process. It is reflected in application of public opinion to the legal resolution of issues at both national and local levels.In the process of legal creation, consideration of public opinion should be carried out at all stages, as at the initiative of the adoption of legal acts, discussion of draft regulations, their coordination and adoption.

The activness of citizens is especially evident in discussion of draft legal acts. To ensure their discussion, draft acts are published in the press, other media (radio and television) are used for this purpose, the bill is sent to interested enterprises, organizations, institutions for discussion at meetings of labor collectives, etc.

According to the definition given in the legal literature, social thought is a state of public consciousness, which is manifested in the attitude to social events, the activities of various groups, associations, economic and other problems[11, p. 323].

In our view, the problems in the field of legislation are among them, and it is useful for the legislature to take into account the formed public opinion in relation to the legislation in its activities.

Because social thought is one of the components of social psychology, it affects the formation of individual, groups, community, their direction, habits, traditions, interests. Social thought includes intellectual, emotional, and volitional components, various observations, and expresses people's attitudes toward issues and events that affect their needs.This attitude can be manifested in the form of evaluation, desire, approval, critical thinking, demand, and so on. Social thought appears during the discussion of social events, life, working conditions[11, $\mathrm{p}$. 323].

However, the legal creativity of public organizations should not be confused with the activity of issuing corporate norms on the regulation of relations between its members[5, $p$. 277].

It is obvious that the direct participation of citizens in development and adoption of legal acts is the evidence of democracy of the law-making process, which allows:

- generalization and taking into account the wishes and interests of citizens, their views on changes and improvements in the draft legislation;

- identification of various weak points in the expression of draft regulations, errors, their prevention and elimination, as well as the adoption of comprehensive and effective legal acts;

- timely raising the issue of amending or repealing obsolete acts that hinder social development;

- identification of social needs that require immediate legal regulation;

- development of new, improved solutions;

- to increase the political activity of the representatives of the public, to help them better understand the instructions of legal acts, to observe them and to help them to fulfill the requirements of legal norms, etc. 
This democratization of the legislative process does not happen by itself, but by taking into account public opinion. In order to make it more effective, in our opinion, it is necessary to do the following:

- further development of the legislator's public relations;

- effective use of various forms of direct democracy;

- preliminary discussion of draft legal acts among the public, labor unions, settlements;

- widespread introduction of the practice of publishing legal acts and comments on them in the press, as well as discussing draft acts, appealing to the public to participate in making the necessary proposals.

"In the context of democratization of society, public opinion plays a particularly important role, while having a positive impact on state activity and law and order, the dissemination of the initiative of the working masses and the formation of a new human personality",[10, p. 3] - wrote S. L. Yunusova.

Supporting the view, we believe that in order to democratize society and increase the effectiveness of the use of public opinion in the legislative process, the following should be done:

- improving the methodology of studying public opinion;

- pay more attention to the proposals and opinions of citizens on draft laws, their timely consideration, generalization and special accounting in the development of legislation;

- increaseing the legal culture of population. This serves to ensure that the general public is involved in law-making knowing the nature of the issue;

- expanding legal guarantees and opportunities for the use of the results of public opinion in the development of legal documents.

\section{References:}

1. Berneys E. L. The Later Years. Public Relations Insigts. 1956-1986. - Rhinebeck: Free Press. 1986. - P. 12.

2. Dubovitskiy V.N. Sociology law: subject, methodology and methods / V.N. Dubovitskiy; Belorussia state university. - Minsk : Lawandeconomy, 2010. -P.21.

3. Karimov I. A. Important tasks of deepening democratic reforms in today's stage // Innovative thinking and working is a demand of time. T.5. - T.: Uzbekistan, 1997. - P. 121.

4. Kahharov A. Public opinion: development mechanism // Topical problems of formation and studing of public opinion in Uzbekistan. Materials of scientific and practical seminar - T.: "Public opinion" center of studying of public opinion, 2003. - P. 58.

5. Lazarev.V.V., LipenS.V. Saidov A.H. Theory of state and law. Textbook. Edited byAcad.Abdurahmanova A.K. -M.:PublisherRus. econ.acad., 2007. P.277.

6. International seminar materials "Estimation of laws and effectiveness of their adoption". 16-17 December 2002. Ryazan. - M., 2002, -P. 23.

7. Nizomulmulk. Policy or siyar ul-mulk. - Т.: Адолат, 1997. - Р. 77.

8. Ruzmetov H. I. About application of achievements of legal sciences in law-making process // Хуқуқ-Право-Law. 2003. Edition 4. -P. 27.

9. Saithodjayev H.B. Sociology. -T.:2017. -P.247.

10. Yunusova S. L. The role of public opinion in perfection of legislation. Abstract of the dissertation. candidate of law science - T., 1993. - P. 3.

11. Law dictionary / Author Nikitin A. F. - M.: Olma-press education, 2005. - P. 323.

12. GrevtsovYu.I. Social law. -SPb., 2001. -P. 277, 277-299, 280, 283-284. 